\title{
Photoshop and Deceptive Advertising: An Analysis of Blog Comments
}

\author{
David S. Waller \\ Correspondence: David S. Waller, Senior Lecturer, University of Technology Sydney, PO Box 123, Broadway, NSW 2007, \\ Australia
}

Received: May 6, 2015 Accepted: May 21, 2015 Online Published: May 25, 2015

doi:10.11114/smc.v3i1.841

URL: http://dx.doi.org/10.11114/smc.v3i1. 841

\begin{abstract}
The advertising industry is often criticized for presenting unrealistic images of fashion and beauty which can have a negative influence on women and girls. In particular, a small number of advertisements for cosmetics have come under fire from advertising regulators in the UK and USA. This exploratory paper discusses two magazine advertisements for mascara which came to the attention of by the US regulatory authority (National Advertising Division of the Council of Better Business Bureaus) "for excessive photoshopping", leading to both ads being withdrawn from future campaigns. Using content analysis, the paper will analyze bloggers' comments about the decision to discover what were the main issues raised.
\end{abstract}

Keywords: advertising, photoshop, deceptive advertising, blogs

\section{Introduction}

Advertising and the media in general are regularly criticized for the way they portray women, particularly use of young models, the continuing of stereotypes, demeaning women, being sexually suggestive, and depicting unrealistic body images. The reasons why advertisers promote these controversial images vary, and include to get the attention of potential customers, strategically obtain publicity, reinforce a specific brand image, and to sell their product, such as fashion, perfume and cosmetics (Waller 1999). However, these images can also have a negative effect on women and girls as they compare and try to reach the unattainable standards set by the media. That effect includes low self-esteem, depression, eating disorders like anorexia and bulimia, exercise addictions, unhealthy attitudes towards sex, sexuality and body image, and in extreme cases can lead to suicide (Hargreaves and Tiggemann 2002; Lavine, Sweeney and Wagner 1999; Tiggemann et al 2013).

The portrayal of women in advertising and magazines has been a research issue for many years, especially focusing on stereotypes and the sexualization of women (for example, Baker 2005; Brett and Cantor 1998; Englis, Solomon and Ashmore 1994; Johnson 2010; Millard and Grant 2006; O'Neil 2014; Stankiewicz and Rosselli 2008). More recently with the development of advanced graphics editing programs like Photoshop, images can be changed, manipulated, and altered resulting in an image that may be unlike the original model, which increases the unrealistic standard set by some advertising images (Tiggemann et al 2013).

In the last few years advertising regulator in the UK (Advertising Standards Authority) has been concerned with the images used in magazine advertisement for fashion (Miu Miu), fragrances (Oh, Lola!) and cosmetics (Christian Dior, Lancome and Maybelline). However, of note is the decision by the United States advertising authority, the National Advertising Division of the Council of Business Bureaus Claims (NAD), to ban an advertisement for CoverGirl for "excessive Photoshopping". This was seen as a landmark decision and a crackdown on "excessive Photoshopping" (Krupnick 2011). Two years later, another mascara advertisement, this time by Maybelline, came to the attention of the NAD but was withdrawn (Barribeau 2013). While this issue has come to the attention of advertising authorities, what is the attitude of the general public?

The growth of the internet and especially blog websites has resulted in people being more empowered to complain about advertising that they deem offensive (Huang et al. 2007; Kerr et al 2012). This gives researchers an opportunity to discover what issues are concerning them in relation to a current topic that is being discussed, in this case, the banning of advertisements that are deemed to have "excessive Photoshopping".

This exploratory paper will discuss the advertising of cosmetics, particularly the CoverGirl and Maybelline advertisements, and analyze blog comments from a number of websites about the decision to determine some feedback 
from the public. The Research Objectives are (1) to discover what were the main issues raised in relation to the NAD decisions by bloggers (as an example of postinteraction judgments); and (2) to determine how important the issues of deception and body image were in relation to the blog comments. A sentiment analysis was undertaken of blog comments posted on websites that presented the stories immediately after the decisions. From the blog comments a number of issues have been raised by 'netisens' about the advertisements, the decision and the industry in general. This contributes to the body of knowledge by observing an important decision by the US regulator, and analyzing the related blog comments to discover peoples' attitudes towards the decision. It is believed that this paper will add to the discourse on the use of photoshopping in advertisements, as well as advertising regulation and web comments.

\section{Literature Review}

\subsection{Deception in Advertising}

A continuing complaint against advertising is that many advertisements are misleading or untruthful and deceive consumers, resulting in a general mistrust of advertising among consumers (Darke \& Ritchie, 2007). While some advertisers have made overtly false or misleading claims, it is their legal and social responsibility to be honest (O'Neil 2014). Yet, deception can occur more subtly as a result of how consumers perceive the ad and its impact on their beliefs. The difficulty of determining just what constitutes deception, along with the fact that advertisers have the right to use puffery and make subjective claims about their products, tends to complicate the issue (Haan \& Berkey, 2002). In most countries the industry and government attempt to regulate and control deceptive advertising in all its forms for the protection of the community.

In this study the theoretical underpinning that will be used is based on 'information manipulation theory (IMT) (McCornack 1992; McCornack et al. 1992) which has its foundations in communication theory. IMT analyzes the communication process and context between senders and receivers of messages with particular interest in the way messages are transmitted from a sender to a receiver in order to give a false impression. This can be done by controlling the facts in the information provided, or omitting, altering or falsifying the information. This deceptive message is a type of communication whereby the receiver is asked to believe something that is untrue. This differs from Interpersonal Deception Theory (IDT) (Buller and Burgoon 1996) as IMT is concerned about the content of the messages and why they are used.

In general, deceptive behavior may or may not be able to be detected by the receiver. In reality there is perceived to be a 'social contract' that a person will be honest with others, and so everyone will be honest with them. However, if the sender manipulates information to omit or falsify relevant information, the receiver will become more aware of the potential deceptive behavior which can result in a negative moral judgment on the sender. Therefore, borrowing from IDT literature (Buller \& Burgoon 1996), after there has been deceptive communication, there develops a "postinteraction judgment" regarding the credibility of the sender. In this study 'postinteraction judgments' will be analyzed by reviewing comments from bloggers.

A criticism of advertising is that there is a potential for deception and dishonesty (O'Neil 2014), hence the establishment of advertising regulatory bodies in countries around the world. So in the case of advertising, the receiver, or audience of the advertising message, will view the advertisement and make judgments on the credibility of the sender.

\subsection{National Advertising Division (NAD)}

Advertising is regulated within countries through various laws and regulations enforced by the particular government agencies. The government is the most important source of regulation, particularly those relating to the need to be truthful and honest in advertisements. As well as government legislation, the advertising industry in many countries has practised and promoted a system of voluntary self-regulation. The importance of maintaining consumer trust and confidence is recognized by advertisers, their agencies and the media so they will self-regulate to set industry standards and guidelines, underpinned by the government regulations.

In the USA the Advertising Self-Regulatory Council (ASRC) [www.asrcreviews.org], until 2012 known as National Advertising Review Council (NARC), is the advertising industry's self-regulatory body. Administered by the Council of Better Business Bureaus (CBBB), the ASRC establishes the policies and procedures for advertising industry self-regulation, including the National Advertising Division (NAD). The mission of the NAD is "to review national advertising for truthfulness and accuracy and foster public confidence in the credibility of advertising" (http://www.bbb.org/us/national-advertising-division). Therefore, the NAD monitors factual claims made in advertisements, and investigates complaints filed by individual consumers or groups, or advertisements referred by local Better Business Bureaus. This paper discusses one of the decisions made by the NAD relating to an advertisement by CoverGirl, and the consumer reaction to it.

Example 1: CoverGirl Advertisement 
CoverGirl is a major cosmetic company based in the US and owned by Procter and Gamble. Its promotion over the years has focused on celebrities to be the representative of CoverGirl. Some of the faces of CoverGirl include: Cybill Shepherd, Christie Brinkley. Drew Barrymore, Ellen DeGeneres, Rihanna, Queen Latifah, and Taylor Swift. Singer, songwriter and teen idol Taylor Swift was the model in a magazine advertisement for CoverGirl's Nature Luxe Mousse Mascara. The advertisement appeared in magazines like the US edition of Vogue (December 2011, page 109). The advertisement presents a picture of Taylor Swift with hair flowing in the breeze. In the copy it claims that the mascara will give your lashes " $2 x$ more volume" and is " 20 per cent lighter" than other mascaras. At the bottom of the picture there was a disclaimer "lashes enhanced in post-production" in fine print.

In late 2011 the NAD reviewed the advertisement after some complaints, and although there were claims that it banned the advertisement "for excessive photoshopping", The director of the NAD, Andrea Levine, said: "You can't use a photograph to demonstrate how a cosmetic will look after it is applied to a woman's face and then - in the mice typehave a disclosure that says 'okay, not really'" (Levine 2011). Procter and Gamble agreed to retract the advertisement. According to a statement:

"Upon receiving the inquiry from the National Advertising Division, Procter and Gamble discontinued the advertisement in question. The National Advertising Division has deemed our intervention as accurate and proper. We have always been committed, and we continue to be committed, to featuring visuals and claims that accurately represent our products' benefits". (Anon 2011).

However, in another statement they appeared surprised by the decision, Brent Miller, CoverGirl spokesman, said: "Retouching is standard, and post-production is standard across all advertising ... Everyone does it" (Seigel 2012). It was claimed that "this is the first major ban by the NAD. The ban marks the beginning of the NAD's supposed crackdown on excessive photoshopping" (Krupnick 2011), and a potential "sea change" as there will be more scrutiny of advertising images (Seigel 2012).

\section{Example 2: Maybelline Advertisement}

Less than 18 months later another mascara advertisement came to the attention of the NAD, this time it was an advertisement for Maybelline, from L'Oreal. The advertisement was for Maybelline's Volum' Express line of mascara, and had an image of a model next to a tiger with the claim that the product can result in "7x more volume". However, in a complaint by competitor Proctor \& Gamble, it was noted that the advertisement was shown in the United States without any disclaimer, yet appeared in Canada and the United Kingdom with the disclaimer "Lashes were enhanced in post-production" (Barribeau 2013; Edwards 2013).

After the complaint was made, the NAD approached L'Oreal who stated that it had already permanently discontinued the advertisement, and so the NAD closed its investigation into the matter. In a statement the NAD said they felt L'Oreal's actions in ending the campaign were "necessary and proper" (ASCR 2013). However, L'Oreal responded by claiming: that the company "supports industry self-regulation and appreciates NAD's consideration of this matter. Although L'Oreal disagrees with the challenger's characterization of our advertising, we did not file a response on the merits because, as noted in NAD's decision, most of the advertising no longer was in use when the challenge was filed except for a few items that we already were in the process of updating." (ASCR 2013).

An interesting aspect of the second case is the lack of response from the media, which generally ignored it. While the decision of the Covergirl advertisement received world-wide attention, the issue surrounding the Maybelline advertisement received little comment in the press (Barribeau 2013; Edwards 2013; Zhang 2013).

\section{Methodology}

A sentiment analysis of web comments from blogs was used to discover blogger's opinion about the NAD decision. Sentiment analysis, or opinion mining, is a form of content analysis that attempts to identify opinions and sentiment from text, such as blogs and online message boards (Pang and Lee 2008). In December 2011 the decision was made by NAD, and it became a newsworthy story which appeared in several newspapers, websites, and blogs around the world. Some of the newspaper sites also asked the readers to give their view on the story. This is a valuable source of data. Weblogs are a substantial platform for communicating opinions by members of the general public (Herring et al 2004; Mishne and Glance, 2006), and can help in exploring alternative views (Chopin, 2008), and are a timed record of both attitudes and behaviors (Huang et al., 2007). For this study the sample is being collected from websites on 20 and 21 December 2011, immediately after the decision was posted in the news stories. Using the search engine Google a search was undertaken which sourced a total of 3,500 links. The main links that were related to newspapers or well-known websites were viewed and then those with more than 10 comments were reviewed. This resulted in 7 websites being analyzed included the Huffington Post, Washington Post, the Daily Mail and Yahoo TV which generated 467 comments. 
As mentioned above, the story of the Maybelline advertisement was not considered newsworthy, and an online search similar to the one undertaken for the Covergirl advertisement discovered three news stories with only one having 11 blog comments. A summary of the websites is found in Table 1.

Table 1. Summary of Blogs Analyzed

\begin{tabular}{llll}
\hline & Web Address & Number of Posts & Country \\
\hline Covergirl Advertisement & & & USA \\
The Huffington Post & www.huffingtonpost.com & 297 & UK \\
Yahoo UK & www.yahoo.co.uk & 55 & UK \\
The Daily Mail & www.dailymail.co.uk & 42 & USA \\
Yahoo TV & Tv.yahoo.com & 38 & Australia \\
Yahoo Australia & Wwwau.lifestyle.yahoo.com & 12 & New Zealand \\
Yahoo New Zealand & www.nz.yahoo.com & 12 & USA \\
Washington Post & www.washingtonpost.com & 11 & 467 \\
Maybelline Advertisement & & & USA
\end{tabular}

To analyze the web comments, the researcher first analyzed the comments from one major website and developed categories which were described for a coding dictionary. Two coders were then used to analyze the comments and identify them in relation to the categories and classify them based on the comments general sentiment as to whether it was "positive", "negative" or "neutral". For this paper the coders independently categorized the comments, and then compared the results. After the first attempt of categorizing comments it was decided that two extra categories be included. Once the comments were categorized comments, a review occurred and any differences were resolved between the two judges resulting in high inter-judge reliability. From the 467 comments a number were rejected as they were irrelevant, mischievous, advertising, or inappropriate, leaving a total of 358 comments that were decided to be included in the final analysis.

\section{Results}

\subsection{Postinteraction Judgments from Bloggers}

To answer the Research Objectives, a sentiment analysis was used to discover what were the main issues raised in relation to the NAD decision by bloggers. This would be an example of postinteraction judgment, as the respondents were commenting on the advertisement after the NAD decision. From the sentiment analysis a total of 10 categories were developed for the 358 comments in the sample (Table 2). Rather than body image or the ethics of photoshopping images, the main topic was regarding the model (Taylor Swift). The comments were varied, but 10 were positive about Taylor Swift, like "I love Taylor Swift!!", while the safety of the internet allowed 20 to be very negative towards her, mainly about her singing, for example: "Yes, but who is out there to protect us from Taylor Swift's music?". 
Table 2. Summary of Blog Comments

\begin{tabular}{|c|c|c|c|c|}
\hline & Positive & Negative & Neutral & Total \\
\hline \multicolumn{5}{|l|}{ Covergirl Advertisement } \\
\hline \multirow[t]{2}{*}{ Model } & 19 & 64 & 6 & 89 \\
\hline & $21.35 \%$ & $71.91 \%$ & $6.74 \%$ & \\
\hline \multirow[t]{2}{*}{ Other Ads } & 2 & 65 & 1 & 68 \\
\hline & $2.94 \%$ & $95.59 \%$ & 1.47 & \\
\hline \multirow{2}{*}{\multicolumn{2}{|c|}{ Industry In General }} & 63 & & 63 \\
\hline & & $100 \%$ & & \\
\hline \multirow[t]{2}{*}{ Decision } & 39 & 13 & 9 & 61 \\
\hline & $63.94 \%$ & $21.31 \%$ & 14.75 & \\
\hline \multirow[t]{2}{*}{ Execution } & & 33 & & 39 \\
\hline & & $84.62 \%$ & 15.38 & \\
\hline \multirow[t]{2}{*}{ Product } & 1 & 11 & & 14 \\
\hline & $7.14 \%$ & $78.57 \%$ & $14.29 \%$ & \\
\hline \multirow[t]{2}{*}{ Effect On Girls/Children } & & 8 & & 8 \\
\hline & & $100 \%$ & & \\
\hline \multirow[t]{2}{*}{ Story In General } & & 7 & & 7 \\
\hline & & $100 \%$ & & \\
\hline \multirow[t]{2}{*}{ Photoshop } & 1 & 2 & 4 & 7 \\
\hline & $14.29 \%$ & $28.57 \%$ & $57.14 \%$ & \\
\hline \multirow[t]{2}{*}{ Correction } & & & 2 & 2 \\
\hline & & & $100 \%$ & \\
\hline \multirow[t]{2}{*}{ Total } & 62 & 266 & 30 & 358 \\
\hline \multirow{2}{*}{\multicolumn{5}{|c|}{ MAYBELLINE ADVERTISEMENT }} \\
\hline & & & & \\
\hline \multirow{2}{*}{ Execution } & & 4 & 3 & 7 \\
\hline & & $57.1 \%$ & $42.9 \%$ & \\
\hline \multirow[t]{2}{*}{ Decision } & 2 & & & 2 \\
\hline & $100 \%$ & & & \\
\hline \multirow[t]{2}{*}{ Photoshop } & & & & 2 \\
\hline & 2 & 4 & $\begin{array}{l}100 \% \\
5\end{array}$ & 11 \\
\hline
\end{tabular}

In their comments, 26 related the decision to advertisements for other products, including fast food, fashion and hair products. For example: "It's the same with those shampoo ads on telly...like pantene - I do not believe that these ads are not enhanced." "Has anyone ever - EVER! - received a McDonald's or Checker's hamburger that looked like the one in the commercials? Anyone with any common sense knows the purpose of advertising is to entice you to buy the product.", and "Advertising that lies, NO! What's next fast food that bad for you?"

Also being a year from the US Presidential election, a number of comments related to politicians and the government. These included: "Lying is all around you, people lie, your friends lie, politicians lie, movies are visual lies, lies are a commonplace fact of life, and that's the truth!", "lying in advertisement...lying in politics...this is what happens when people love money more than they love people...GREED and lying go hand in hand", "We seem to have become a society where a statement is only a lie if someone calls attention to it. But we have been being lied to by politicians for years, and no one seems to care. In fact, many many people just accept what they say as the truth and act on it. Suggesting that even our government is built on lies. And the Supreme Court supports it as an act of free speech. So I guess photo shopping is free speech too.", and "Funny how stretching the truth about mascara is enough to get an ad banned, but political lies are just standard operating procedure. Gee, which one would I rather be protected from? Mascara that won't make me as beautiful as Taylor Swift or corporate funded political campaigns that seek to destroy my country in the service of greed and corruption?".

One article from the Daily Mail mentioned "Make Up Forever", a cosmetic brand that uses natural beauty to promote its product, which is why there are 2 positive comments relating to other advertisements.

The majority of people were positive about the decision: "About time! USA far behind UK re: misleading beauty ads. Now please stop the airbrushing away of wrinkles of mature models and the use of teenagers to promote anti-aging cosmetics", "I can't believe it's taken so long. NAD should have done this long ago", and "I am absolutely delighted at this decision. ... Well done NAD, may your desire for honesty in pictures gain momentum".

Although there were some who disagreed with the decision, for example: "Ridiculous! EVERY mascara ad claims the same garbage but ALL of the models wear false lashes. Now that this ad put a disclaimer on the bottom, THIS company gets back-lash? (*no pun intended) Ridiculous! Go after the companies that FALSELY ADVERTISE, not the ones who put the truth somewhere in a disclaimer. Duh!"

Another topic that received over 20 comments was about the industry in general. These comments indicated that people thought that it was usual practice for the cosmetic industry to lie in their advertisements. For example: "I thought it's pretty obvious that most makeup ads, especially lash ads, are "enhanced."”, "Well it annoys the you know what out of me 
when I see mascara commercials and it's obvious to anyone with two brain cells that the models are wearing false eyelashes. I don't buy their products", and "Business as usual in the marketing world. There's not one ad out there that shows "actual" results. Everything is retouched!"

Finally, of the main categories, there were comments about the execution of the advertisement, which were mainly negative, for example: "that's not what a human is supposed to look like. That's why we hate this ad".

As for the Maybelline advertisement, only 11 comments were analyzed, with the majority commenting negatively on the execution, while there were also comments on the decision and photoshop. Two negative comments about the execution were:

"I dont get how this kind of advertising is not classified as false. If you artificially enhance lashes in a mascara commercial, to me that is plainly exaggerating the function of the product. This seems totally deceptive and untruthful.", and sarcastically:

"Companies should have a right to mass market a lie to people as long as it has a notice that is too small for most people to read (and usually too quick if on TV) and show their product doing something it doesn't do? You want a precedent of unethical business practice?"

One comment provided some advice about using photoshop in advertising:

"How to maintain product credibility: Photoshop do's and dont's

Makeup / mascara / anti-aging cream ads:

DO: remove stray hairs, alter hair or eye colour if desired, whiten and straighten teeth if necessary.

DON'T: remove skin blemishes, wrinkles, scars, etc.

Why? BECAUSE THAT'S WHAT THE PRODUCT IS SUPPOSED TO DO! How do you expect consumers to trust your product if you don't trust it yourself?!

To sum things up. Keep it real!"

Therefore, these 10 categories answer the Research Objective by discovering what were the main issues raised in relation to the NAD decision by bloggers, as an example of postinteraction judgment. The results indicated that in relation to the importance of the issues of deception and body image, the bloggers did mention the problem of deception and credibility in advertising, particularly in relation to other types of advertising, and what goes on in the beauty industry in general. The issue of body image was rarely mentioned, although there were concerns related to the effect of such advertising on girls and children.

\section{Discussion and Conclusion}

The analysis of the 358 blog comments indicated some specific meanings of the advertising message from the bloggers, in particular, a relationship between the communications process, the context and the attitudes towards/of the senders/receivers of messages. Many respondents made comments about the advertisement, specifically the model, product and the execution, without indicating determined deceptive behavior, which could reflect the 'social contract' that assumes that people will act honestly. However, a large number of bloggers have clearly developed a set of "postinteraction judgements" in which they have not only decided that the sender of this message, CoverGirl, lacked credibility of the sender, but so did other advertisers, indicating that the receiver had developed a high level of suspicion towards particular types of advertisers/senders.

The wider public policy issues are raised on the use of photoshop in advertising images and how these images can have a negative effect on women and girls, especially relating to body image and unattainable standards set by the media. They look unattainable because often they are, unless there is enhancement via post-production. However, this aspect was given little mention by the bloggers. Still, the original decision by the NAD is, therefore, a significant one. It has been described as "the beginning of the NAD's supposed crackdown on excessive photoshopping" (Krupnick 2011), and a potential "sea change" (Seigel 2012), and with 18 months another advertisement came to the attention of the NAD.

More recently the issue of photoshopping came into the public's focus with a bipartisan Bill, the "Truth in Advertising Act" that was introduced by Ileana Ros-Lehtinen (Republican) and Lois Capps \& Ted Deutch (Democrat), with support from various groups like the Eating Disorders Coalition \& the Brave Girls Alliance (Seeley 2014/15). The purpose of the Act is:

"To direct the Federal Trade Commission to submit to Congress a report on the use, in advertising and other media for the promotion of commercial products, of images that have been altered to materially change the physical characteristics of the faces and bodies of the individuals depicted." (Truth in Advertising Act of 2014, www.govtrack.us/congress/bills/113/hr4341/text). 
However, the extent that photoshopping in general can be banned seems impractical, so it will be important to monitor what will be the real effect of this proposed Bill and NAD decision.

After briefly discussing the controversy surrounding the portrayal of women in advertising and the unrealistic standards they can set, the advertisements for CoverGirl \& Maybelline show that the companies actually admitted that the images in their advertisements is not real, but "enhanced in post-production", which is an unusual example of "truth in advertising'. Yet, the advertisements were criticized by the US regulatory authority, NAD, and no longer published. To understand the general public's reaction the analysis of blog comments revealed that most of the comments for the Covergirl advertisement relate to the model (Taylor Swift), agreeing to the decision, and other advertisements, which is in accordance with postinteraction judgment. The theoretical implication of broadening the concept of postinteraction attitudes provides a better understanding of attitudes towards potentially deceptive/misleading advertising and the use of blog comments in general. However, even though the result of the Covergirl advertisement is recognized as a significant decision by the NAD, the issue is whether this will mark a change in the images targeted towards women and girls, or this was a one-off decision.

Further research is highly recommended on deceptive advertising and the portrayal of women in advertisements and media, its use of post-production editing and its effect on women and girls. It has been suggested that this decision by the NAD could be the beginning of changes to the advertising of cosmetics and the use of Photoshop, however, many blog comments indicate that many believe this is normal for the industry. Future studies are also encouraged to monitor the use of and attitudes towards photoshop and other postproduction enhancement in advertisements for cosmetic, fashion and beauty-related products, and present theories explaining the perception of the target audience. Only time will tell if this decision by the NAD will have a long standing effect on the advertising and the beauty industries.

\section{References}

Anon (2011). Taylor Swift's ad banned for being too photoshopped. NDTV Movies.com Music, 22 December. Found at: http://movies.ndtv.com/music/taylor-swift-s-ad-banned-for-being-too-photoshopped-159925.

ASCR Press Release. (2013). NAD Finds L'Oreal Acted Properly in Discontinuing Mascara Advertising that Incorporated Post-Production 'Enhancement' Disclosure. www.asrcreviews.org/2013/03/nad-finds-loreal-acted-properly-in-discontinuing-mascara-advertising-that-incorpor ated-post-production-enhancement-disclosure/.

Baker, C. N. (2005). Images of women's sexuality in advertisements: A content analysis of Black- and White-oriented women's and men's magazines. Sex Roles, 52, 13-27. http://dx.doi.org/10.1007/s11199-005-1190-y

Barribeau, T. (2013). L’Oreal pulls mascara ads for excessive Photoshopping, 20 March, www.imaging-resource.com/news/2013/03/20/loreal-pulls-mascara-ads-for-excessive-photoshopping.

Brett, D. J., \& Cantor, J. (1998). The portrayal of men and women in US television commercials: a recent content analysis and trends of 15 years. Sex Roles, 18 (9/10), 595-608.

Buller, D. B., \& Burgoon, J. K. (1996). Interpersonal deception theory. Communication theory, 6(3), $203-242$. http://dx.doi.org/10.1111/j.1468-2885.1996.tb00127.x

Chopin, K. (2008). Finding communities: alternative viewpoints through weblogs and tagging. Journal of Documentation, 64(4), 552-575. http://dx.doi.org/10.1108/00220410810884075

Darke, P. R., \& Ritchie, R. J. (2007). The defensive consumer: Advertising deception, defensive processing, and distrust. Journal of Marketing Research, 114-127. http://dx.doi.org/10.1509/jmkr.44.1.114

Edwards, J. (2013). L'Oreal Pulled All These Ads Because They Used Too Much Photoshop. Business Insider, www.businessinsider.com.au/loreal-pulled-mascara-ads-because-of-photoshop-2013-3?op=1\#its-not-clear-from-th e-nad-ruling-exactly-which-ads-were-pulled-but-loreal-agreed-to-pull-all-of-them-including-its-in-store-signage-fo r-brands-such-as-maybelline-volum-express-falsies-1.

Englis, B., Solomon, M., \& Ashmore, R. (1994). Beauty before the eyes of beholders: the cultural encoding of beauty types in magazine advertising and music television. Journal of Advertising, 23, 49-64. http://dx.doi.org/10.1080/00913367.1994.10673441

Haan, P., \& Berkey, C. (2002). A study of the believability of the forms of puffery. Journal of Marketing Communications, 8(4), 243-256. http://dx.doi.org/10.1080/13527260210162282

Hargreaves, D., \& Tiggemann, M. (2002). The effect of television commercials on mood and body dissatisfaction: The role of appearance-schema activation. Journal of Social and Clinical Psychology, 21(3), 287-308. http://dx.doi.org/10.1521/jscp.21.3.287.22532

Herring, S. C. (2009). Web content analysis: Expanding the paradigm. In Hunsinger, J., Klastrup, L. and Allen, M. (eds.) 
The international handbook of Internet research. Dortrecht, The Netherlands: Springer Verlag. http://dx.doi.org/10.1007/978-1-4020-9789-8_14

Herring, S. C., Sheidt L. A., Bonus, S., \& Wright, E. (2004). Bridging the gap: a genre analysis of weblogs. In: Proceedings of the $37^{\text {th }}$ annual Hawaii international conference on system sciences (HICSS '04). IEEE Computer Society, Los Alamitos, CA: 101-111. http://dx.doi.org/10.1109/hicss.2004.1265271

Huang, C., Shen, Y., Lin, H., \& Chang, S. (2007). Bloggers' motivations and behaviours: A model. Journal of Advertising Research, 472-484. http://dx.doi.org/10.2501/S0021849907070493

Johnson, V. M. (2010). Female Undergraduate Students' Perceptions of the Portrayal of Women in Advertising. Theses and Professional Projects from the College of Journalism and Mass Communications, 3. http://digitalcommons.unl.edu/journalismdiss/3.

Kerr, G., Mortimer, K., Dickinson, S., \& Waller, D. S. (2012). Buy, Boycott or Blog: Exploring online consumer power to share, discuss and distribute controversial advertising messages. European Journal of Marketing, 46(3/4), 387-405. http://dx.doi.org/10.1108/03090561211202521

Krupnick, E. (2011). CoverGirl Mascara Ad Banned -- By CoverGirl -- For Excessive Photoshopping, The Huffington Post, www.huffingtonpost.com/2011/12/20/covergirl-mascara-ad-banned_n_1159957.html

Lavine, H., Sweeney, D., \& Wagner, S. H. (1999). Depicting women as sex objects in television advertising: Effects on body dissatisfaction. Personality and Social Psychology Bulletin, 25, 1049-1058. http://dx.doi.org/10.1177/01461672992511012

Levine, A. (2011). NAD Case Report 5400.

McCornack, S. A. (1992). Information manipulation theory. Communication Monographs, 59, 1-16. http://dx.doi.org/10.1080/03637759209376245

McCornack, S. A, Levine, T. R., Solowczuk, K. A., Torres, H. I., \& Campbell, D. M. (1992). When the alteration of information is viewed as deception: An empirical test of information manipulation theory. Communication Monographs, 59, 17-29. http://dx.doi.org/10.1080/03637759209376246

Millard, J. E., \& Grant, P. R. (2006). The stereotypes of Black and White women in fashion magazine photographs: The pose of the model and the impression she creates. Sex Roles, 54, 659-673. http://dx.doi.org/10.1007/s11199-006-9032-0

Mishne, G., \& Glance, N. (2006). Leave a reply: an analysis of weblog comments. In: Proceedings of the 3rd annual workshop on the weblogging ecosystem: aggregation, analysis and dynamics. WWW2006, 22-26 May Edinburgh, UK.

O'Neil, Ashley (2014). A Call for Truth in the Fashion Pages: What Global Trend in Advertising Regulation Means for U.S. Beauty and Fashion Advertisers. Indiana Journal of Global Legal Studies, 21(2). http://www.repository.law.indiana.edu/ijgls/vol21/iss2/9.

Pang, B., \& Lee, L. (2008). Opinion mining and sentiment analysis. Now Publishers Inc. http://dx.doi.org/10.1561/1500000011

Seeley, B. (2014/15). The Most Important Congressional Bill You Haven't Yet Heard Of, Huffington Post. www.huffingtonpost.com/bri-seeley/the-best-bill-in-congress-youve-probably-never-heard-of_b_6288744.html

Seigel, J. (2012). The Lash Stand: Will new attitudes and regulatory oversight hit delete on some photo retouching in print ads? Adweek. Found at: www.adweek.com/news/press/lash-stand-140785

Stankiewicz, J.M., \& Rosselli, F. (2008). Women as sex objects and victims in print advertisements. Sex Roles, 57, 579-589. http://dx.doi.org/10.1007/s11199-007-9359-1

Tiggemann, M., Slater, A., Bury, B., Hawkins, K., \& Firth, B. (2013). Disclaimer labels on fashion magazine advertisements: Effects on social comparison and body dissatisfaction. Body image, 10(1), $45-53$. http://dx.doi.org/10.1016/j.bodyim.2012.08.001

Waller, D. S. (1999). Attitudes towards offensive advertising: An Australian study. Journal of Consumer Marketing, 16 (3), 288-294. http://dx.doi.org/10.1108/07363769910271513

Zhang, M. (2013). L'Oreal Pulls Ads, Saying They Used Too Much Photoshop, PetaPixel, 20 March. http://petapixel.com/2013/03/20/loreal-pulls-ads-saying-they-used-too-much-photoshop.

\section{(cc) $\mathrm{BY}$}

This work is licensed under a Creative Commons Attribution 3.0 License. 